\title{
Translating Catullus 85: why and how*
}

\section{Armand D'Angour}

Jesus College, University of Oxford

Turl Street, Oxford, OX1 3DW, United Kingdom; armand.dangour@jesus.ox.ac.uk

For citation: Armand D’Angour. Translating Catullus 85: why and how. Philologia Classica 2019, 14(1), 155-160. https://doi.org/10.21638/11701/spbu20.2019.113

This article argues that in the first verse of Catullus' epigram 85, the commonly found translation of quare as 'why' in English versions since the $17^{\text {th }}$ century, but particularly in translations produced in the last fifty years, cannot be accepted. In the context of Catullus's poetry, with poems 72 and 75 offering an explicit background to and rationale for the contradiction in the poet's feelings between love and hate, and in the light of the incontrovertible connotation of quare (or qua re) as 'how' in a passage of Terence's Eunuchus, the correct translation of the word can only be 'how'. Some suggestions are made to account for the origins and the persistence of the mistranslation. The translation as 'why' in the prose version in the 1912 Loeb edition edited by F. W. Cornish is suggested to have influenced a generation of English-speaking students, and Martial's epigram 1.32 is invoked as a cause. But it is further argued that in taking Catullus's epigram as a model for his own, Martial may have expressly intended to suggest that the meaning of quare as 'why' that was current in his time was different in that very respect from the connotation 'how' clearly intended by his predecessor.

Keywords: Catullus, epigram 85, quare, translation.

Odi et amo; quare id faciam fortasse requiris: nescio, sed fieri sentio et excrucior.

The brevity of this couplet is inversely proportional to the quantity of words written about it and the plethora of attempts to translate it. Yet despite that volume, more needs to be said about an issue central to its interpretation, because its meaning has almost universally been distorted (notably in the past fifty years of scholarship and reception) by the persistent rendering into English of quare in line 1 as 'why'. Thus three fairly recent versions run as follows:

"I hate and love. Perhaps you're asking why I do that?

I don't know, but I feel it happening, and am racked."

"I hate and love. You wonder, perhaps, why I do that?

I have no idea. I just feel it. I am crucified." ${ }^{2}$

* I am indebted to Ellen Oliensis for her insightful feedback on the first draft of this article, and to Tatiana Kostyleva and the readers for Philologia Classica for their helpful contributions.

${ }^{1}$ Lee 1998, 131.

${ }^{2}$ Green 2005, 190.

(C) St. Petersburg State University, 2019 
"I hate and love.

Perhaps you wonder why.

I don't know, but I feel it, and I am crucified."3

That this understanding (or misunderstanding) of the meaning of quare is not just a recent phenomenon is illustrated by the translation of the $17^{\text {th }}$-century poet Richard Lovelace (1617-1657):

I hate and love; would'st thou the reason know?

I know not, but I burn, and feel it so.

Translators of the $18^{\text {th }}$ and $19^{\text {th }}$ centuries, including Walter Savage Landor, Charles Lamb, Richard Francis Burton, and the Scots poet Theodore Martin, concurred with Lovelace in penning versions with 'why' or 'wherefore', to be followed in the $20^{\text {th }}$ century by, among others, the Eton schoolmaster Francis Warre Cornish (editor of the popular Loeb edition of Catullus that appeared in 1912), Ezra Pound, and C. H. Sisson. ${ }^{4}$ Yet Lovelace's direct contemporary Abraham Cowley (1618-1667) offers this version using 'how':

I hate, and yet I love thee too,

How can that be? I know not how;

Only that so it is I know

And feel with torment that 'tis so.

And in a brief note published in 1923 J.P. Postgate, the scholarly editor of Catullus (1889), approvingly quotes two very similar translations of the poem with 'how' published in 1909 and 1912, the earlier one by the classicist J. Wight Duff:

I hate, yet love. You ask how this may be.

Who knows? I feel its truth and agony. ${ }^{5}$

Postgate was a contributor to the Loeb edition edited by Cornish, which became a prime source for the study of Catullus in English-speaking schools. It is, however, Cornish's prose translation that stands in that edition, and was to remain when the Loeb was subsequently revised by G. P. Goold in 1976:

I hate and love. Why I do so, perhaps you ask?

I know not, but I feel it, and I am in torment.

I propose here first to show that quare in this poem cannot mean 'why' or 'the reason', and then briefly to suggest one reason why such a mistranslation might have arisen and subsequently persisted within the scholarly community. 'The poem represents the ultimate stage in a process of condensation of thought and expression', comments Thom-

${ }^{3}$ Uzzi and Thomson 2015, 148. The most recent translation that I know, that of Daisy Dunn (2016), also translates 'why'.

${ }^{4}$ A selection of English translations of C. 85 may conveniently be accessed online at https://briefpoems.wordpress.com/tag/catullus/.

${ }^{5}$ Postgate 1923. 
son, 'earlier stages in which are represented by poems 72 and 75.6 In C. 72 (eight lines), Catullus addresses Lesbia as one who once reciprocated his whole-hearted love, but has now injured him by her infidelities. The result is that his love burns for her more fiercely (impensius uror, 5, cogit amare magis, 8), but he feels less benignly loving towards her (sed bene velle minus, 8). In C. 75 (four lines), he repeats that although he no longer feels goodwill towards her (bene velle, 3), he cannot cease being in love with her (desistere amare, 4). The opposition expressed in C. 85 is therefore readily understandable in terms of this repeatedly explained conflict of feelings. The contrasting emotions the poet feels for his once wholly beloved Lesbia have arisen due to her injurious and culpable conduct towards him (iniuria, 72. 7, culpa, 75.1). The substance of that culpa is expanded in C.11.22 with the exaggeratedly vivid image of Lesbia 'embracing three hundred lovers at the same time, loving none truly but busting their groins over and over again'. C. 85 sums up in its two lines the conflict of hate and love that rages in Catullus's heart, ending with the powerful (and barely metaphorical) verb excrucior, 'I am being torn in two on the rack.' ${ }^{7}$ The poet presents himself as dying in torment as if hate is literally pulling him in one direction, love in another; he is being torn apart by these opposite forces. This is not something, he tells us, over which he has any choice: he is not doing it (faciam), it is being done to him (fieri). In both grammar and feeling, the shift from active to passive is a piercing acknowledgment of his helplessness.

The 1969 translation by James Michie avoids both 'why' and 'how', but neatly elucidates the meaning of the poem in these terms:

\section{I hate and love. If you ask me to explain \\ The contradiction iscepi \\ I can't, but I can feel it, and the pain \\ Is crucifixion. ${ }^{8}$}

If the apparent contradiction odi et amo were to elicit a question from the reader, it might well be reckoned 'why are you doing that?' An appropriate enough answer to that question might be 'I'm not doing it: I feel it being done to me' (fieri sentio). In C. 85, however, that answer is importantly preceded by nescio: that is, the immediate and unqualified answer to the question Catullus imagines the reader to pose is 'I don't know'. Yet the fact is that, as we have seen, Catullus does know why; he more than once makes clear elsewhere precisely why he is undergoing this excruciating torment. The reason is elucidated in the two poems cited earlier, and the situation is no less evident in others. He hates Lesbia for the iniuria she inflicts on him, yet his love or desire for her persists and is even stronger as a result of her conduct; that is why he both hates and loves. The verbal and emotional logic is unimpeachable, and thoroughly characteristic of Catullus: if the poet were not still in love with Lesbia, he would not be hating her for her treatment of him. It will not do to say 'Logic (2: nescio) has failed; all that remains is feeling (2: sentio) painful to the point of torture (excrucior). ${ }^{9}$ The problem is that both emotions somehow persist simultaneously,

6 Thomson 1997, ad loc.

7 The literal meaning of crux is more likely be 'rack' than 'cross'; cruciari in this period is used to connote 'torture' in general rather than crucifixion.

${ }^{8}$ Michie 1969.

9 Green 2005, 261. 
and both poet and reader will be in no doubt about the cause of that painfully contradictory state of mind.

To the question 'why are you doing that?', then, the poet's answer could not have been nescio. Asked for the reason or cause of his action, the answer Catullus would surely give, as he gives elsewhere, is 'because of the way I'm treated by the woman I used to love unreservedly'. Let us, then, examine what else quare might mean. While all later citations of the term point to the connotation 'why', the earliest citation, standardly printed as two separate words, is found in an exchange between the slave Parmeno and the youth Chaerea in Terence's Eunuchus of 161 BC:

\section{PA. quid si nunc tute fortunatu' fias? \\ PA. capias tu illi $(u)$ s vestem.}

"PA: What if you were to get lucky now? PA: Take that man's clothes.

\author{
$\mathrm{CH}$. qua re, Parmeno? responde. \\ $\mathrm{CH}$. vestem? quid tum postea? ${ }^{10}$ \\ $\mathrm{CH}$ : How, Parmeno? Tell me. \\ $\mathrm{CH}$ : His clothes? And then what?"
}

The meaning we must attribute here to qua re is unequivocal: it is not 'why', but 'how', literally 'by what thing' (the instrumental ablative, emphasised by the spelling of qua re as two separate words, prompts a tangible answer - 'this dress'). And while this is an early and admittedly rare occurrence of the word with that connotation, it is easy to see how 'by what thing' or 'by what means' may come to mean 'in what way' or 'how', and it is certain that such a usage, one that preserves the instrumental nature of the locution, would have been known to Catullus. ${ }^{11}$

Taking Catullus' quare to mean 'how' rather than 'why' resolves a host of unclarities. First, the statement odi et amo has been posed as, and is instantly interpretable as, a kind of paradox: hate and love, directed towards the same object by the same mind, surely cannot coexist. The poet appears to represent himself acting per impossibile. The obvious question to ask is not why he should be so acting, but how it is possible for him to do so. Secondly, 'how are you doing that?' is a question to which the answer nescio makes perfect sense. These emotions might be thought logically, and practically, incompatible. If one loves, how can one also hate? Should not love drive out its opposite, or vice versa? If one hates, can one still be susceptible to love? Yet that is the position that Catullus finds himself in, and we know why. What we don't know, and what the poet admits to not knowing, is how such a contradictory state of mind is possible. All he can observe is what he feels (sentio), a bewildering conjunction of negative and positive feelings to which he must succumb and which are not of his choosing, but the effects of which he is all too painfully aware.

Many readers of the poem have understood and will understand this meaning of quare to be 'how', and a fair number of translations published in the century prior to 1960 favour that translation. ${ }^{12}$ Since then, however, the misguided and confusing translation 'why' has held sway, with remarkably few exceptions. ${ }^{13}$ Why might this be? One possible reason is the reliance in English-speaking scholarship on the 1912 Loeb transla-

10 Ter. Eun. 369-370.

11 Similar usages of quare to mean 'by which means, whereby' are found in Nepos (Cat. 2.3) and Cicero (Rosc. Am. 33.94).

12 Translators using 'how', with publication dates, include: Robert Tyrrell (1895), Charles Stuttaford (1912), Hugh McNaghten (1925), and Roy Arthur Swanson (1959).

13 Daniel Selden 1992, 541, translates quare as 'how', without explanation or comment. 
tion originally edited by Cornish and revised by Goold. But another may be that learned readers have allowed themselves to be misled by the occurrence of quare meaning 'why' in another famous epigram, Martial 1.32. ${ }^{14}$ Writing over a century after Catullus, Martial plays on the notion expressed in C. 85 with an elegiac distich of his own in which quare is used unmistakeably to connote 'why':

\section{Non amo te Sabidi, nec possum dicere quare: \\ Sed tantum hoc possum dicere: non amo te. \\ "I don't like you, Sabidius, nor can I say why: \\ All I can say is this: I don't like you."}

For the witty later poet, the attitude here presented is not a question of passionate, unrequited love of the kind to which Catullus refers, but simply a matter of like or dislike. And in this case there is no question about the poet doing or feeling both things simultaneously: the issue is simply about disliking Sabidius. Martial does not, therefore, need to suppose that his reader's response might perhaps be to ask 'how'; no question need arise here about how he might dislike Sabidius, only the question of why he does so. ${ }^{15}$ In that case, Martial continues, he cannot say why; the implication, as in Catullus's case, is that this is a feeling that cannot be explained. However, this is far from the Catullan encapsulation of his tormented, paradoxical feelings, of the kind that might well elicit from a reader the question of how it might be possible.

The distich has added point and wit, however, if we recognise that Martial understood himself to be offering a deliberate misreading of Catullus's quare (or qua re), which he will have understood correctly to mean 'how'. If one imagines quare in inverted commas (non possum dicere 'quare') Martial would be slyly indicating 'I cannot say 'quare' in the way Catullus does'. That is, he is unable to use the word in the sense that his predecessor has used it, because he has no reason to ask 'how', only 'why'; whereas Catullus, who was able to employ the word in a sense no longer current in Martial's time, clearly did mean 'how'. In this way, Martial's nec possum dicere quare, 'nor can I say why', instead of providing a guide for the understanding of quare as 'why', does the opposite: it offers itself as a guarantor of the true meaning of Catullus' quare as 'how'. In the light of this analysis, therefore, I offer here one further translation:

I hate and love; perhaps you ask how both of these I do.

I don't know: I just feel it, and it's tearing me in two.

14 E. g. Lorenz (2007) begins his chapter on 'Catullus and Martial' by drawing the parallel, and cites scholarship that does so dating from 1876; he also notes that it was the model for the popular 'I do not love thee, Doctor Fell' (Howell 1980, 176-8). That version, attributed to the satirical writer Thomas Brown (1662-1704) continues 'The reason why I cannot tell'. The countless retellings of the certainly apocryphal but appealing tale of how Brown allegedly escaped expulsion at the hands of Dean Fell of Christ Church by thus translating the couplet at sight will have embedded the mistaken notion in the minds of many translators that quare in Catullus must similarly be taken to mean 'the reason why'.

${ }_{15}$ Nothing is known of Sabidius, so the nature of Martial's actual relationship with him or the reason for his dislike can only be a matter of speculation. No such knowledge is required for the reader to appreciate the barbed humour of the epigram. 


\section{References}

Dunn D. The Poems of Catullus. London, William Collins, 2016.

Green P. The Poems of Catullus: A Bilingual Edition. Berkeley, University of California Press, 2005.

Howell P. A Commentary on Book 1 of the Epigrams of Martial. London, Athlone Press, 1980.

Lee G. Catullus: The Complete Poems. Oxford, OUP, 1998.

Lorenz, S. Catullus and Martial, in: M. Skinner (ed.) A Companion to Catullus, Malden, MA - Oxford, Blackwell, 2007, 418-438.

Michie J. The Poems of Catullus. New York, Random House, 1969.

Postgate J. P. A Translation from Catullus. The Classical Review 1923, 37, 67-68.

Selden D. Ceveat Lector: Catullus and the Rhetoric of Performance, in: R. Hexter and D. Selden (eds). Innovations of Antiquity. Abingdon, Routledge, 1992, 461-512.

Thomson D. F. S. (ed.) Catullus. Toronto, University of Toronto Press, 1997.

Uzzi J. D., Thomson J. The Poems of Catullus. Cambridge, CUP, 2015. 